Boise State University

ScholarWorks

9-14-2016

It's Not Just What You Know, But Who You Know: Social Capital Theory and Academic Library Outreach

Elizabeth Ramsey

Boise State University 
This is an author-produced, peer-reviewed version of this article. The final, definitive version of this document can be found online at College \& Undergraduate Libraries, published by Routledge. Copyright restrictions may apply. doi: 10.1080/10691316.2016.1206317

\title{
It's Not Just What You Know, But Who You Know: Social Capital Theory and Academic Library Outreach
}

\author{
Elizabeth Ramsey, MLS \\ Albertsons Library \\ Boise State University
}

Column Series Title: Reflections on Academic Library Outreach

\begin{abstract}
The concept of social capital and its contribution to success and well-being in a variety of settings has potential for academic library outreach. Research has found that those with extensive and varied networks of social relationships can benefit in myriad ways, including academic and professional achievement. A connection has also been found between lower levels of social capital and negative effects on individuals as well as communities generally. Academic libraries are strategically positioned to enhance the social capital of their users, effecting positive differences in engagement, retention, and success after graduation.
\end{abstract}

Keywords: academic libraries, social capital, networking, outreach, retention, engagement

\section{Author Introduction}

Like quite a few academic librarians, I came to the field after working in other professions, including graphic design, and teaching English as a foreign language. Although I have taken a circuitous route to my current position, my former jobs have served me well as outreach coordinator for Albertsons Library at Boise State University. Throughout my varied careers I have learned how to analyze user needs, how to find, organize, and present materials to meet those needs, and how to assess the effectiveness of the materials and their presentation.

Cross cultural awareness has been a key factor in the successful navigation of responsibilities throughout my professional life. It also informs my current research agenda, as well as material for this column. Through this column I hope to investigate and summarize theories and practical ideas aimed at developing thoughtful outreach practices that both reflect and embrace the diverse, multi-layered identities of our community members.

\section{Introduction}

The notion that someone who is well connected can benefit from their social connections is embedded in human society. People tap into their personal and professional networks for entry into groups, clubs, schools, and businesses. Through connections people gain an edge on what they know and when they know it, parlaying that knowledge into opportune decision making. Networks of partnerships and collaborations allow individuals, groups, and institutions to achieve aims that would have been more difficult, if not impossible, without those connections. For well-connected college students, the social capital edge might result in any number of boosts to their academic and professional pursuits: a timely connection to a tutor, information about a scholarship, news about an internship opportunity that includes experience toward future employment, or perhaps a mentorship that leads them to consider a career they had never envisioned for themselves.

Although social networks have been a useful tool since, conceivably, human civilization began, the idea of a person or group's social relationships providing capital in the form of intangible resources has been a relatively new concept for research. The number of published articles on social capital grew enormously in the '90s, with sociologists Bourdieu, Coleman, and Putnam often identified as seminal researchers on the topic. Social capital has since grown to be examined in relation to education, economics, civic engagement, and other aspects of the well-being of both individuals and communities, although little of that research has been applied to libraries, particularly academic libraries. This article will start with a brief overview of some aspects of social capital research literature as context for 
This is an author-produced, peer-reviewed version of this article. The final, definitive version of this document can be found online at College \& Undergraduate Libraries, published by Routledge. Copyright restrictions may apply. doi: 10.1080/10691316.2016.1206317

its application to academic library outreach. For the purposes of this article, outreach is defined as those efforts designed to engage users with library staff, services, or resources. It encompasses instruction, programming, committee and other collaborative work, and social media use.

\section{Literature Review}

Definitions of social capital are many and varied, depending on what aspects of the concept are the focus of the definition. Social scientists Adler and Kwon define social capital as "the goodwill that is engendered by the fabric of social relations and that can be mobilized to facilitate action.”(2002, 17) Other social scientists, such as Field, describe the networks of relationships themselves as the valued goods, or capital, in the term social capital (2003b). For Woolcock, social capital includes not only the networks, but also the norms that facilitate collective action (2002, 25). While definitions vary, most research agrees that social capital provides measurable benefits to individuals, institutions, and communities.

With its strategic networking function, social capital is a natural for research in connection with business and management principles. Erickson examined social capital as an asset to both employers and employees in the hiring process with an emphasis on the added value of variety in social networks that include both close and more loosely held connections (2001). Marsden noted the importance of the ability to form networks of contacts and maneuver within those networks as key to effective job performance, particularly in those involving customer service (2001, 108). Information access and timing are also benefits of strong social capital noted by Burt (1997), who later summarized the value of social capital simply, "Better connected people enjoy higher returns" (2001, 32). Those who start building their networks of relationships during their college years are better prepared for their job searches than those who rely solely on their classroom experiences. Academic libraries can contribute to this process through opportunities to strategically connect to other people, making use of a kind of resource not usually counted in library collections.

Higher returns for those with higher levels of social capital have also been noted in education. Coleman found a family's social capital to be a strong predictor of educational attainment for children regardless of other variables such as socioeconomic standing (1988). Field observed that individuals use their social capital to increase their access to learning, "People with the largest and most tested networks can be expected to have more access to information, including information both about the potential value of new skills or knowledge, as well as about the potential effectiveness of different types of learning resource" (2003a, 145). Kilpatrick, Field and Falk noted a connection between social capital and learning in that the socially connected are more likely to know where to go for resources on how to get things done $(2003,425)$. Schuller stated that social capital affected educational achievement at not only the individual, but also the institutional and system levels $(2007,21)$.

The observed effects of higher levels of social capital on education are similar to many academic libraries' stated missions, values, and/or goals. In fact, some academic libraries are already integrating this human network potential into their mission statements, such as, "The vision of the UCLA Science and Engineering Library is to provide our users seamless access to onsite and world-wide information services and to support the delivery of the information with a creative internal network of human and material resources" (italics added, http://www.library.ucla.edu/sel/about/vision-values-mission-goals). By making concerted efforts to connect people to people as well as to more standard library resources such as instruction, databases, and books, academic libraries can strengthen their students' ability to successfully achieve their educational goals.

Social capital theory has been embraced by not only social scientists in a variety of fields, but also the World Bank and the Organization for Economic Development and Co-operation (OECD) in their development efforts. The World Bank provides a Social Capital Library as well as a series of working papers as part of their Social Development Department. The OECD also supports research on social capital; in a report for the OECD, Scrivens and Smith offer a wide-ranging yet detailed potential research agenda on the measurable effects of social capital on individual as well as community well-being (2013). Further, the OECD provides a databank of survey responses on the topic to support further statistical analysis of social capital and its implications. These resources provide evidence of social capital's value as a viable and measurable variable in human and community development. 
This is an author-produced, peer-reviewed version of this article. The final, definitive version of this document can be found online at College \& Undergraduate Libraries, published by Routledge. Copyright restrictions may apply. doi: 10.1080/10691316.2016.1206317

Like the World Bank and OECD, libraries are committed to supporting the growth of both individuals and their communities. Thus, it is surprising that so little research on libraries and social capital exists. Most of what does exists focuses on public libraries, although the American Library Association's past-president, Nancy Kranich, noted in her blog the important service libraries generally provide in building the social capital of diverse users to foster their contributions to a civil society (November 15, 2001). Hillenbrand, too, underlined libraries' commitment to inclusiveness as a core library value underpinning efforts that result in stronger social capital for library users (2005). Bourke called on public libraries to support the development of social capital by being "visible and active in their communities, constantly looking for new ways to build bridges to the excluded and marginalized" $(2005,74)$. Varheim, Steinmo and Ide observed that in being a universal service institution public libraries naturally create social capital $(2008,882)$.

While the programming and services ascribed to public libraries by these researchers are certainly part of academic libraries, the literature on social capital and academic libraries is even scantier than that connected to public libraries. What can be found is largely limited to social capital implications of participation in academic libraries' social networking sites. Ellison, who has produced several studies on the topic, concluded in her 2007 article that, "Because bridging social capital provides benefits such as increased information and opportunities, we suspect that participants who use Facebook in this way are able to get more out of their college experience" (Ellison, Steinfield, and Lampe 1163). It is reasonable to conclude that the social capital capabilities ascribed to college students by Ellison through their Facebook use may also be attributable to other outreach efforts by academic libraries. Because social capital can benefit students in the profound and far-reaching manner described by documented research, it is in the best interest of academic libraries to consider social capital development as a component of their outreach.

\section{Potential of Social Capital in Academic Library Outreach}

Strong social capital has been found to enhance access to information, enabling better self-advocacy, better informed decisions, and more effective participation in educational, professional, and civic institutions. Research has also shown that those with weaker social capital may be less successful at completing their college education or competing professionally after they graduate. Through a variety of outreach initiatives, academic libraries can help these marginalized populations to enhance their social capital, along with their abilities to achieve educational and professional goals.

It should be noted that marginalization, an effect of a myriad of identity factors, can also be a consequence of the negative side of social capital. Social capital acts, for the good and bad, as a reinforcement of social norms. This means that closed networks of relationships can act to exclude non-members, underpin disadvantages, or support collusion, as in the case of good old boy networks or criminal gangs. Woolcock cautioned that the absence of social ties has an equally important impact, in that when a person is not a member of, or is even actively excluded from, certain social networks and institutions, they are left "out of the loop" (2002, 22). This can be seen at university in first generation students or students from disadvantaged socioeconomic or educational backgrounds, who may arrive on campus unaware of the ways that university systems are set up to support them. In addition, students from non-majority populations face identity contingencies and stereotype threats that can undermine their academic performance, yet these students may have few options in terms of trusted connections on campus that offer affirmations and shared narratives as a counterbalance. Academic libraries can act to counter the effects of the dark side of social capital through strategic outreach efforts that not only inform their students, but help them form the social connections that could benefit them throughout their lives.

\section{Operationalizing Social Capital}

Libraries have always excelled at connecting users with resources; however, if they want to truly have a lifelong impact on their users, they will have to consider ways to also help build connections between people as well as more traditional resources. Hillenbrand delineated ways in which public libraries create social capital that are certainly also part of academic libraries' outreach repertoire, including, among others: delivering inclusive programming, providing equitable access to information, enhancing information literacy skills, creating partnerships with other community organizations, and providing a public space for the community $(2005,9)$.

A growing number of academic libraries are sharing their buildings with other student services such as writing centers, academic advising, and career services; partnering with these services connects students to people dedicated to their 
This is an author-produced, peer-reviewed version of this article. The final, definitive version of this document can be found online at College \& Undergraduate Libraries, published by Routledge. Copyright restrictions may apply. doi: 10.1080/10691316.2016.1206317

well-being and success, helping students build their network of relationships on campus, and thus their social networks. Those libraries that do not or cannot offer office space to these types of services can still provide meeting rooms and programming that can afford similar results.

While formal programming can benefit students in forming relationships with people in positions to support their academic and professional goals, some research has found that more informal connections are also effective at building social capital. Putnam observed, "Extracurricular activities and involvement in peer social networks are powerful predictors of college dropout rates and college success" $(2000,306)$. Given this finding, academic libraries that provide meeting spaces for student groups, or programming developed by and for those groups, may be facilitating the kind of informal connections needed for student success.

Instruction, too, can provide strategic opportunities to help students build beneficial relationships with their peers and others on campus. Group work in class is an opportunity for students to start connecting with peers. Library instruction and tours could focus on not only library resources, but also on introductions to faculty and public services staff in the library with whom students are likely to interact. "Deliberately arranged interactions can help people get to know each other, and develop networks. The interactions can also increase people's confidence...” (Kilpatrick, Field, and Falk 2003, 425).

Social networking sites such as Facebook, Twitter and Instagram can function as some of the most powerful builders of social capital. Research has found that, contrary to common belief, computer mediated relationships have positive effects on community interaction and the development of social capital (Wellman et al. 2001). Ellison, Steinfeld, and Lampe came to similar conclusions when observing a more specific population, college students, in their use of Facebook. The researchers observed that this social networking site allowed students to create and maintain the large, diffuse networks of relationships that are the hallmark of social capital, "Such connections could have strong payoffs in terms of jobs, internships, and other opportunities.” (2007, 1164). Academic libraries can help foster these important connections by engaging students through social networking sites.

\section{Conclusion}

This brief overview of social capital concepts introduces evidence from social science to support the notion that academic libraries are strategically situated to positively affect students' social capital, and thus, their abilities to effectively navigate college life and beyond. Because little research has been conducted on social capital theory as it relates to academic library efforts, the topic is ripe for further exploration. Academic libraries struggle to provide statistical data supporting their part in student success and retention; this topic might provide an area for quantifiable analysis. While this article has focused on students, these concepts may also have application to faculty, staff, and community patrons. Hopefully, this article will spur not only further research on the topic, but also act to help academic libraries engage with their patrons in a way that more strategically reaches out to their marginalized populations.

\section{References}

Adler, Paul S., and Seok-Woo Kwon. 2002. "Social capital: Prospects for a New Concept." Academy of Management Review 27 (1): 17-40.

Bourke, Carolyn. 2005. "Public libraries: Building Social Capital Through Networking." Australasian Public Libraries and Information Services 18 (2): 71.

Burt, Ronald S. 1997. "The Contingent Value of Social Capital." Administrative Science Quarterly 42 (2): 339-365.

Burt, Ronald S. 2001. "Structural Holes versus Network Closure as Social Capital.” Edited by Lin, Nan, Karen S. Cook, and Ronald S. Burt. Social Capital: Theory and Research. New York: Aldine de Gruyte. 31-56.

Coleman, James S. 1998. "Social Capital in the Creation of Human Capital." American Journal of Sociology 94: 95120.

Ellison, Nicole B., Charles Steinfield, and Cliff Lampe. 2007. "The Benefits of Facebook "Friends:” Social Capital and College Students’ Use of Online Social Network Sites." Journal of Computer-Mediated Communication 12, (4): 1143-1168.

Erickson, Bonnie H. 2001. "Good Networks and Good Jobs" The Value of Social Capital to Employers and Employees.” Edited by Lin, Nan, Karen S. Cook, and Ronald S. Burt. Social Capital: Theory and Research. New York: Aldine de Gruyte. 127-158. 
This is an author-produced, peer-reviewed version of this article. The final, definitive version of this document can be found online at College \& Undergraduate Libraries, published by Routledge. Copyright restrictions may apply. doi: 10.1080/10691316.2016.1206317

Field, John. 2003a. "Civic Engagement and Lifelong Learning: Survey Findings on Social Capital and Attitudes Towards Learning." Studies in the Education of Adults 35 (2): 142-156.

Field, John. 2003b. Social Capital. London: Routledge.

Hillenbrand, Candy. 2005. "Public Libraries as Developers of Social Capital." Australasian Public Libraries and Information Services 18 (1): 4-12.

Kilpatrick, Sue, John Field, and Ian Falk. 2003. "Social Capital: An Analytical Tool for Exploring Lifelong Learning and Community Development." British Educational Research Journal 29 (3): 417-433.

Kranich, Nancy. “Libraries Create Social Capital.” Library Journal (blog). November 15, 2001. http://lj.libraryjournal.com/2001/11/library-services/libraries-create-social-capital/\#_

Marsden, Peter V. 2001. “Interpersonal Ties, Social Capital, and Employer Staffing Practices.” Edited by Lin, Nan, Karen S. Cook, and Ronald S. Burt. Social Capital: Theory and Research. New York: Aldine de Gruyte. 105-126.

Putnam, Robert D. 2000. Bowling Alone: The Collapse and Revival of American Community. New York: Simon \& Schuster.

Putnam, Robert. 2001. "Social Capital: Measurement and Consequences" Canadian Journal of Policy Research 2 (1): 41-51.

Schuller, Tom. 2007. "Reflections on the Use of Social Capital." Review of Social Economy 65 (1): 11-28.

Scrivens, K. and C. Smith. 2013. "Four Interpretations of Social Capital: An Agenda for Measurement”, OECD Statistics Working Papers. OECD Publishing. http://dx.doi.org/10.1787/5jzbcx010wmt-en

Steinfield, Charles, Nicole B. Ellison, and Cliff Lampe. 2008. "Social Capital, Self Esteem, and Use of Online Social Network Sites: A Longitudinal Analysis." Journal of Applied Developmental Psychology 29 (6): 434-445.

Vårheim, Andreas, Sven Steinmo, and Eisaku Ide. 2008. "Do Libraries Matter? Public Libraries and the Creation of Social Capital." Journal of Documentation 64 (6): 877-892.

Wellman, Barry, Anabel Quan Haase, James Witte, and Keith Hampton. 2001. "Does the Internet Increase, Decrease, or Supplement Social Capital? Social Networks, Participation, and Community Commitment." American Behavioral Scientist 45 (3): 436-455.

Woolcock, Michael. 2002. "Social Capital in Theory and Practice: Reducing Poverty by Building Partnerships Between States, Markets and Civil Society." Social Capital and Poverty Reduction: Which Role for the Civil Society Organizations and the State. Paris: United Nations Educational, Cultural and Scientific Organizations. 20-44. 